\title{
Standardization and Quality Evaluation of Sour Cream Enriched Therapeutic Food Products
}

\author{
S.D. Katke ${ }^{1 *}$, Mohammed Abdur Rahman ${ }^{2}$ and P.S. Patil ${ }^{3}$ \\ ${ }^{1}$ Department of Food Microbiology \& Safety, College of Food Technology, \\ VNMKV, Parbhani, India \\ ${ }^{2}$ Department of Food Technology, Sam Higg in bottom University of Agriculture, \\ Technology and Sciences, Allahabad, (U.P.), India \\ ${ }^{3}$ Department of Food Science \& Technology, MIT College of Food Technology, \\ Aurangabad, India \\ *Corresponding author
}

\section{A B S T R A C T}

\section{Keywords}

Sour cream, Sour cream spread, Sour cream salad, Lactobacillus acidophilus, Streptococcus lactis, Sour cream boondi raita

Article Info

Accepted:

12 February 2019

Available Online:

10 March 2019
The present investigation focuses on standardizing the process for preparation of sour cream enriched therapeutic food products. Sour cream was prepared by ripening of cream with the addition $6 \%$ culture of Lactic Acid Bacteria (Lactobacillus acidophilus and Streptococcus lactis) culture and $0.2 \%$ xanthan gum. The prepared sample of sour cream was further used in the exploration of food preparation i.e. sour cream spread, sour cream salad and boondi raita. Sensory characteristics of sour cream spread, sour cream salad and boondi raita were studied. It was found that sour cream spread with red chili sauce and salad with $20 \%$ sour cream had higher overall acceptability which was evidently proved by statistical analysis. Boondi raita prepared with sour cream was found to be more acceptable than the one prepared with curd. Further, the shelf life of sour cream enriched therapeutic food products is found to be for four weeks at the refrigerated storage condition.

\section{Introduction}

Fermented milk products, known as cultured dairy products, or cultured milk products, are dairy foods that have been fermented with Lactic Acid Bacteria. Fermented milk products, besides their nutritive value, have been reported to have therapeutic properties.
They are supposed to be anticholesterolomic and anticarcinogenic. They are considered superior to non-fermented dairy products in terms of nutritional attributes as the micro flora present produce simple compounds like lactic acid, amino acids and free fatty acids that are easily assimilable. A lot of attention is being focused on fermentation technology 
with an aim to tap the possible health benefits conferred by microorganisms (Grajek et al., 2005).

Sour cream is a smooth, heavy-bodied dairy product which is made by pasteurizing, homogenizing and ripening a light cream. The ripening is accomplished by means of a commercial starter containing Streptococcus lactis, together with other flavour-producing bacteria. The pleasant, mild-acid flavour and the smooth, firm body are mainly due to these microorganisms. This product is known on the market as cultured cream, cultured market cream, cultured sour cream and salad cream. Sour cream contains proteins that originate from milk.

Consequently, all the goodness that is present in the case of milk proteins is also there in the case of sour cream proteins. Sour cream is good source of calcium, a mineral; body needs to boost bone health. Each half-cup serving of sour cream provides 13 percent of the daily recommended intake of calcium. In addition to its benefits to skeletal health, the calcium in this condiment is vital for the function of nerves, muscles and heart. One serving of sour cream provides 12 percent of the daily recommended intake of riboflavin, also known as vitamin $\mathrm{B}_{2}, 13 \%$ of the phosphorus required each day.

It is commonly used as a base for dips, salad dressings and sauces. It is eaten as a condiment on potatoes, chili, or with smoked salmon, as well as many other foods. Sour cream can be used in soups and works well in baked products like breads, cakes, pies and cookies.

Sour cream has significantly less calories than mayonnaise and performs many similar functions. It has long been used in the culinary art in the preparation of many dishes and traditional foods.

\section{Materials and Methods}

Pure cultures of Lactobacillus acidophilus and Streptococcus lactis were purchased from National Chemical Laboratory, (NCL) Pune. The whole fresh and clean buffalo milk was obtained from local market. Flavouring ingredients and salad ingredients required for preparation of sour cream spread, sour cream salad and sour cream boondi raita were bought from local market.

\section{Preparation of starter culture}

The starter culture was prepared with the help of method described by Ghadge et al., (2008) with suitable modifications.

\section{Preparation of MRS medium composition of MRS medium}

All the ingredients were suspended in distilled water and heated to dissolve the medium completely. The medium was sterilized in autoclave at $15 \mathrm{lbs}$ pressure for 15 minutes (Deman et al., 1960). The Table 1 shows the composition of MRS medium.

\section{Isolation of lactic acid bacteria from curd}

Serial dilutions (10 fold) were first made. Then the sample of curd after serial dilutions was inoculated into the nutrient broth and incubated at $37^{\circ} \mathrm{C}$ for $24-48$ hours. From nutrient broth the growth was transferred to the nutrient agar for separation of colonies. The selected colonies from nutrient agar were shifted to MRS broth subsequently to MRS agar for isolation and purification.

\section{Purity of the cultures}

The staining of the obtained pure cultures of Lactobacillus acidophilus and Streptococcus lactis was carried out by using Gram staining technique, catalase test, motility test and by determining the growth at $15^{\circ} \mathrm{C}$ and $40^{\circ} \mathrm{C}$ 
Morphology and biochemical confirmation tests

\section{Sub-culturing of pure culture}

The pure cultures i.e. Lactobacillus acidophilus and Streptococcus lactis were sub-cultured on slants prepared from MRS media in a laminar air flow. The prepared slants were incubated at $37^{\circ} \mathrm{C}$ for 24 hours. Growth of cultures was found on slants after 24 hours of incubation (Table 2).

\section{Preparation of sour cream}

Sour cream was prepared using mixed culture of Lactobacillus acidophilus and Streptococcus lactis. Sour cream was prepared according to the procedure depicted by A.J. Kwan et al., (1982) with suitable modifications and is presented in flow chart 1 .

The processing steps included- preparation of cream, standardization of cream fat to $18-19 \%$ fat, pasteurization, cooling, addition of culture and gum and incubation till the acidity of cream reaches upto $0.5 \%$, packaging and storage at $2^{\circ} \mathrm{C}$. It required $20-22$ hours to reach the acidity of sour cream upto $0.5 \%$.

\section{Standardization of cream}

Fat content of cream obtained after the separation of skim milk was estimated by Gerber method. The standardization of cream fat to $19 \%$ was carried out by Pearson's square method (Sukumar de, 1991).

\section{Preparation of inoculum}

The inoculum for the development of sour cream was prepared with the help of method described in Beshkova et al., (1998) with suitable modifications. The method involves the addition of pure culture to the buffalo milk.
The loopful of cultures present on MRS slant were inoculated to the two different test tubes each containing of $10 \mathrm{ml}$ buffalo milk respectively. The test tubes were further incubated at $45^{\circ} \mathrm{C}$ for 3 hours.

\section{Exploration of sour cream in food preparation}

\section{Preparation of sour cream spread with flavouring ingredients}

Sour cream spread can be used as a substitute for mayonnaise in different food preparations. It was prepared with different flavouring ingredients according to the procedure given in Flow chart 1. Experimental control had no added flavouring ingredient and only contained sour cream while the flavouring ingredients used in the preparation of sour cream spread samples were Jaljira Masala, Red Chili Sauce, Green Chili Sauce. The formulation of sour cream spread is given in Table 3 .

\section{Preparation of sour cream salad}

Sour cream salad was prepared using various ingredients. The ingredients used in the preparation of salad included cabbage, cucumber, tomato, carrot, pomegranate, grapes, chili sauce, spinach, chat masala and salt. The formulation for preparation of sour cream salad is given in Table 4. Sour cream salad was prepared according to the procedure given in Flow chart 2. Experimental control contained no sour cream added to the salad while samples A, B and C contained 10 per cent, 15 per cent and 20 per cent sour cream added to the salad respectively.

\section{Preparation of sour cream boondi raita}

Boondi raita is a traditional product prepared using curd. Boondi raita was prepared 
according to the formulation given in Table 5 . The procedure for preparation of boondi raita is given in Flow chart 3. Experimental control contained boondi raita prepared using curd while Sample Contained boondi raita prepared with sour cream.

\section{Results and Discussion}

\section{Proximate analysis of sour cream}

The figures tabulated in Table 6 shows that the fat content of sour cream $(16 \%)$ was less than the fat content of cream $(25 \%)$. The reduction in fat may be due to the microbial activity of Lactic Acid Bacteria. Also there was marginal change in protein content of cream and sour cream i.e. $1.78 \%$ and $1.72 \%$ respectively. Ash content indicates the mineral content of the food. The ash content of cream and sour cream was found to be $0.56 \%$ and $0.79 \%$ respectively. The moisture content of cream and sour cream was $74.20 \%$ and $68.16 \%$ respectively. Cultured products are digested more easily and, therefore, are more nutritious because the proteins, carbohydrates, and fats are predigested by bacterial cultures in their manufacture (Lipatov et al., 1978).

It also indicates that cream contained calcium (111.03 mg/100g), phosphorus (118.0mg/ $100 \mathrm{~g})$, magnesium $(54.6 \mathrm{mg} / 100 \mathrm{~g})$, potassium $(90.7 \mathrm{mg} / 100 \mathrm{~g})$ and sodium $(70.61 \mathrm{mg} / 100 \mathrm{~g})$ while sour cream contained calcium (111.10 $\mathrm{mg} / 100 \mathrm{~g})$, phosphorus $(122.0 \mathrm{mg} / 100 \mathrm{~g})$, magnesium $(56.7 \mathrm{mg} / 100 \mathrm{~g})$, potassium $(104.5$ $\mathrm{mg} / 100 \mathrm{~g})$ and sodium $(62.14 \mathrm{mg} / 100 \mathrm{~g})$. Thus it was observed that sour cream contained higher amount of phosphorus followed by calcium, potassium, magnesium and sodium. Calcium content of cream and sour cream had marginal changes while sour cream contained higher amount phosphorus $(122 \mathrm{mg} / 100 \mathrm{~g})$ than cream $(118.0 \mathrm{mg} / 100 \mathrm{~g})$ and higher amount of potassium $(104.5 \mathrm{mg} / 100 \mathrm{~g})$ than cream $(90.7 \mathrm{mg} / 100 \mathrm{~g})$. Sodium content of sour cream was reduced as compared to cream. Cream contained $70.61 \mathrm{mg} / 100 \mathrm{~g}$ sodium while sour cream than $62.14 \mathrm{mg} / 100 \mathrm{~g}$. The data obtained was in good accordance with the results reported by Khem et al., (1979). it has been observed that the $\mathrm{pH}$, titratable acidity, total solids and solids-not-fat of prepared sour cream was found to be 4.5, 0.5 per cent, 25.8 per cent and 8.9 per cent respectively. The values recorded in the present study are in good accordance with the results patented by Pavey et al., (1976).

\section{Sensory evaluation of sour cream spread with addition of flavouring ingredients}

Sour cream spread was prepared using various flavouring ingredients. The flavour ingredients used included Jaljira Masala, Red Chili Sauce and Green Chili Sauce. The sensory evaluation of sour cream spread with addition of flavour ingredients is summarized in Table 7 and Figure 1.

The values of Table 7 revealed that the highest score for color and appearance was rated for Sample B (8.5) and experimental control (8.5) which was found to be significantly superior to Sample A and Sample C. It was observed that the highest score for taste was found in Sample B (8.4) followed by Sample C (8.1) and Sample A (8.0). Maximum score for flavour was obtained for Sample B (8.6) which was found to be at par with Sample C and significantly superior to Sample A and experimental control. Mouth feel of Sample B was rated the highest i.e. 8.5 while it was rated similar for Sample A and Sample C. Sample B containing red chili sauce flavour had the highest overall acceptability (8.5) which was found to be at par with Sample C (8.2) but significantly higher than Sample $\mathrm{A}$ and experimental control. Thus the Sample B containing red chili sauce as a flavouring 
ingredient in the preparation of sour cream spread was found to be the most acceptable.

\section{Sensory evaluation of sour cream salad}

Sour cream salad was prepared with the addition of different concentration of sour cream into a salad. Sample A, Sample B and Sample C contained 10, 15 and 20 per cent sour cream respectively. Sensory score of sour cream salad is depicted in Table 8.

It was found that the color of samples slightly varied with the addition of sour cream into a salad. Maximum score for color and appearance was recorded for Sample C (8.4) which was found to be at par with Sample B and the experimental control and significantly higher than Sample A. The values shown in Table 8 have evidently proved that increase in concentration of sour cream upto 20 per cent has enhanced the color and appearance of the salad. The taste of the samples had remarkable changes in the sensory values. It has been revealed that Sample C for taste was rated highest (8.7) which was found to be at par with Sample B and significantly higher than Sample A and the experimental control. The addition of sour cream into a salad has imparted sourness thereby enhancing the taste of the salad. The flavour was rated the highest for Sample C (8.6) which was found to be at par with Sample B and was significantly higher than Sample A and the experimental control. Sample C containing 20 per cent sour found to be more appealing than rest of the samples. The enhancement of flavour might be due to the flavours produced by LAB cultures. It was found that the sensory score for mouth feel has been increased in Sample C. Maximum score for mouth feel was obtained for Sample C (8.7) which was found to be at par with the Sample B and was significantly higher than the Sample A and the experimental control. The creaminess of salad with addition of 20 per cent sour cream was found to be increased thereby increasing the mouth feel of salad. Change in overall acceptability of samples was found with increased concentration of sour cream in salad. Maximum score for overall acceptability was found in Sample C (8.7) which was found to be at par with Sample B and significantly higher than Sample A and the experimental control. Thus it was concluded that the overall acceptability was increased with increase in amount of sour cream in the salad (Fig. 2).

\section{Sensory evaluation of sour cream boondi raita}

Boondi raita is a traditional food product which is being prepared with curd. In the present investigation, sour cream was utilized in the preparation of boondi raita. The experimental control constituted the boondi raita prepared with the curd while Sample A was prepared with the sour cream. The sensory score of boondi raita is tabulated in Table 9 and Figure 3.

The figures tabulated in Table 9 revealed that the highest score for color and appearance was obtained for Sample A (8.5) which was found to be significantly higher than the experimental control. Plate-6 shows the differentiation between the experimental control and Sample A. It was observed that the boondi raita prepared with sour cream appeared to be more appealing than the one prepared with curd. Maximum score for taste was obtained for Sample A (8.4) which was found to be at par with the experimental control. This shows that sour cream can be utilized in the preparation of boondi raita. Flavour of samples showed remarkable changes. The highest score was obtained for Sample A (8.3) which was found to be significantly higher than the experimental control. Texture was an important parameter which should be taken into consideration. It 
was found that the highest score for texture was obtained for Sample A which was found to be significantly higher than the experimental control. Mouth feel of both the samples were compared by the panelists. It was found that the highest rating for mouth feel was obtained for Sample A (8.4) which was found to be at par with the experimental control. The thickness of the sour cream imparted and enhanced the mouth feel of the boondi raita. The overall acceptability of boondi raita prepared with curd and sour cream were analyzed. Maximum score for overall acceptability was obtained for Sample A (8.4) which was found to be at par with the experimental control. Thus it can be concluded that sour cream can be a good substitute for curd in the preparation of boondi raita.

\section{Microbial characteristics of sour cream}

The sour cream sample was subjected to microbial studies for total plate count, yeast and mold count and Coliform growth after production and during the storage period as per the method given in the manual of methods of analysis of foods (2012). Microbial characteristic of accepted sour cream sample is tabulated in Table 10. The values of Table 10 show the microbial characteristics of accepted sour cream sample during storage under refrigerated condition. It was revealed that total plate count of the accepted sour cream sample was the highest $\left(8.6 \times 10^{8}\right)$ after the 32 days of storage at refrigerated condition while it was lowest (2.7 $\left.\mathrm{x} 10^{8}\right)$, on the production day. Data presented in Table 10 indicated that total plate count of accepted sour cream sample was $2.7 \times 10^{8}, 4.3$ $\mathrm{x} 10^{8}, 5.8 \times 10^{8}, 7.5 \times 10^{8}, 8.6 \times 10^{8} \mathrm{cfu} / \mathrm{g}$ on day of production, $8,16,24,32$ days after production respectively. Yeast and mold count was not detected till 8 days of refrigerated storage condition while $3 \times 10^{3}, 5$ $\times 10^{3}, 6 \times 10^{3} \mathrm{cfu} / \mathrm{g}$ was detected for 16,24 and 32 days refrigerated storage condition. Coliform was not detected after production and throughout the refrigerated storage period of 32 days in acceptable sample of sour cream. It meant that the accepted sample of sour cream was safe for consumption for the 32 days with the total plate count of $8.6 \mathrm{x}$ $10^{8} \mathrm{cfu} / \mathrm{g}$.

Table.1 Composition of MRS medium

\begin{tabular}{|l|c|}
\hline \multicolumn{1}{|c|}{ Ingredients } & gms/lit \\
\hline Protease peptone & $\mathbf{1 0 . 0}$ \\
\hline Yeast extract & $\mathbf{5 . 0}$ \\
\hline Beef extract & $\mathbf{1 0 . 0}$ \\
\hline Dextrose & $\mathbf{2 0 . 0}$ \\
\hline Polysorbate-80 & 1.0 \\
\hline Ammonium citrate & $\mathbf{2 . 0}$ \\
\hline Sodium acetate & $\mathbf{5 . 0}$ \\
\hline Magnesium sulphate & $\mathbf{0 . 1}$ \\
\hline Manganese sulphate & $\mathbf{0 . 0 5}$ \\
\hline $\begin{array}{l}\text { Di-potassium } \\
\text { phosphate }\end{array}$ & 2 \\
\hline Distilled water & 1 lit \\
\hline
\end{tabular}


Table.2 Morphology and biochemical confirmation tests for Lactobacillus acidophilus and Streptococcus lactis

\begin{tabular}{|l|c|c|}
\hline \multicolumn{1}{|c|}{ Biochemical tests } & $\begin{array}{c}\text { Lactobacillus } \\
\text { acidophilus } \\
\text { Rods, pairs, chains }\end{array}$ & Streptococcus lactis \\
\hline Morphology & + & Cocci \\
\hline Gram staining & - & + \\
\hline Catalase test & - & - \\
\hline Motility & - & - \\
\hline Growth at $\mathbf{1 5}^{\mathbf{0}} \mathbf{C}$ & + & + \\
\hline Growth at $\mathbf{4 5}^{\mathbf{0}} \mathbf{C}$ & & - \\
\hline
\end{tabular}

Table.3 Preparation of Sour Cream Spread using different flavouring ingredients

\begin{tabular}{|c|c|c|c|c|}
\hline Ingredients & EC & $\mathbf{A}$ & B & $\mathbf{C}$ \\
\hline Flavour & - & 20\% Jaljira Masala & 20\% Red Chili Sauce & $20 \%$ Red Chili Sauce \\
\hline Cream $(g)$ & 100 & 100 & 100 & 100 \\
\hline Milk (g) & 48 & 48 & 48 & 48 \\
\hline $\begin{array}{l}\text { Starter } \\
\text { Culture }\end{array}$ & - & 6 & 6 & 6 \\
\hline $\begin{array}{l}\text { Xanthan } \\
\text { Gum }\end{array}$ & - & 0.2 & 0.2 & 0.2 \\
\hline
\end{tabular}

Table.4 Preparation of sour cream salad

\begin{tabular}{|l|c|c|c|c|}
\hline \multicolumn{1}{|c|}{ Ingredients } & EC & A & B & C \\
\hline Sour cream & - & $10 \%$ & $\begin{array}{c}15 \\
\%\end{array}$ & $\begin{array}{c}\mathbf{2 0} \\
\mathbf{\%}\end{array}$ \\
\hline Cabbage & $30 \mathrm{~g}$ & $30 \mathrm{~g}$ & $30 \mathrm{~g}$ & $\mathbf{3 0 g}$ \\
\hline Cucumber & $30 \mathrm{~g}$ & $30 \mathrm{~g}$ & $30 \mathrm{~g}$ & $\mathbf{3 0 g}$ \\
\hline Tomato & $10 \mathrm{~g}$ & $10 \mathrm{~g}$ & $10 \mathrm{~g}$ & $\mathbf{1 0 g}$ \\
\hline Carrot & $10 \mathrm{~g}$ & $10 \mathrm{~g}$ & $10 \mathrm{~g}$ & $\mathbf{1 0 g}$ \\
\hline Pomegranate & $5 \mathrm{~g}$ & $5 \mathrm{~g}$ & $5 \mathrm{~g}$ & $\mathbf{5 g}$ \\
\hline Grapes & $5 \mathrm{~g}$ & $5 \mathrm{~g}$ & $5 \mathrm{~g}$ & $\mathbf{5 g}$ \\
\hline Chili sauce & $5 \mathrm{~g}$ & $5 \mathrm{~g}$ & $5 \mathrm{~g}$ & $\mathbf{5 g}$ \\
\hline Spinach & $2 \mathrm{~g}$ & $2 \mathrm{~g}$ & $2 \mathrm{~g}$ & $\mathbf{2 g}$ \\
\hline Chat masala & $1.5 \mathrm{~g}$ & $1.5 \mathrm{~g}$ & $1.5 \mathrm{~g}$ & $\mathbf{1 . 5 g}$ \\
\hline Salt & $\mathbf{1 . 5 g}$ & $\mathbf{1 . 5 g}$ & $\mathbf{1 . 5 g}$ & $\mathbf{1 . 5 g}$ \\
\hline
\end{tabular}


Table.5 Preparation of sour cream Boondi Raita

\begin{tabular}{|l|c|c|}
\hline \multicolumn{1}{|c|}{ Ingredients } & EC & A \\
\hline Sour cream & - & $\mathbf{8 0 g}$ \\
\hline Curd & $80 \mathrm{~g}$ & - \\
\hline Water & 10 & $\mathbf{1 0}$ \\
$\mathrm{ml}$ & $\mathbf{m l}$ \\
\hline Boondi & $5 \mathrm{~g}$ & $\mathbf{5 g}$ \\
\hline Coriander & $2 \mathrm{~g}$ & $\mathbf{2 g}$ \\
\hline Sugar & $1 \mathrm{~g}$ & $\mathbf{1 g}$ \\
\hline $\begin{array}{l}\text { Red Chili } \\
\text { Powder }\end{array}$ & $1 \mathrm{~g}$ & $\mathbf{1 g}$ \\
\hline Salt & $0.5 \mathrm{~g}$ & $\mathbf{0 . 5 g}$ \\
\hline Chat Masala & $\mathbf{0 . 5 g}$ & $\mathbf{0 . 5 g}$ \\
\hline
\end{tabular}

Table.6 Proximate analysis of sour cream

\begin{tabular}{|c|l|c|c|}
\hline Sr.No. & Chemical constituents & Cream & Sour Cream \\
\hline $\mathbf{1}$ & Moisture & 68.16 & $\mathbf{7 4 . 2 0} \%$ \\
\hline $\mathbf{2}$ & Crude fat & 25 & $\mathbf{1 6} \%$ \\
\hline $\mathbf{3}$ & Crude protein & 1.78 & $\mathbf{1 . 7 2} \%$ \\
\hline $\mathbf{4}$ & Ash & 0.56 & $\mathbf{0 . 7 9} \%$ \\
\hline $\mathbf{5}$ & Carbohydrate & 4.50 & $\mathbf{7 . 2 9} \%$ \\
\hline $\mathbf{6}$ & Calcium & $111.03 \mathrm{mg} / 100 \mathrm{~g}$ & $\mathbf{1 1 1 . 1 0}$ \\
\hline $\mathbf{7}$ & & & $\mathbf{m g} / \mathbf{1 0 0 g}$ \\
\hline $\mathbf{8}$ & Phosphorus & $118.0 \mathrm{mg} / 100 \mathrm{~g}$ & $\mathbf{1 2 2 . 0} \mathbf{~ m g} / \mathbf{1 0 0 g}$ \\
\hline $\mathbf{9}$ & Magnesium & $54.6 \mathrm{mg} / 100 \mathrm{~g}$ & $\mathbf{5 6 . 7} \mathbf{~ m g} / \mathbf{1 0 0 g}$ \\
\hline $\mathbf{1 0}$ & Potassium & $90.7 \mathrm{mg} / 100 \mathrm{~g}$ & $\mathbf{1 0 4 . 5} \mathbf{~ m g} / \mathbf{1 0 0 g}$ \\
\hline $\mathbf{1 1}$ & Sodium & $70.61 \mathrm{mg} / 100 \mathrm{~g}$ & $\mathbf{6 2 . 1 4} \mathbf{~ m g} / \mathbf{1 0 0 g}$ \\
\hline $\mathbf{1 2}$ & Titratable acidity & 4.0 & $\mathbf{4 . 5}$ \\
\hline $\mathbf{1 3}$ & Total solids & $0.3 \%$ & $\mathbf{0 . 5 \%}$ \\
\hline $\mathbf{1 4}$ & Solids-not-fat & $30 \%$ & $\mathbf{2 5 . 8 \%}$ \\
\hline
\end{tabular}


Table.7 Mean sensory values of sour cream spread with addition of flavouring ingredients

\begin{tabular}{|c|c|c|c|c|c|c|}
\hline Sample & $\begin{array}{c}\text { Colour \& } \\
\text { Appearance }\end{array}$ & Taste & $\begin{array}{c}\text { Flavou } \\
\mathbf{r}\end{array}$ & Texture & Mouthfeel & $\begin{array}{c}\text { Overall } \\
\text { Acceptability }\end{array}$ \\
\hline EC & 8.5 & 7.8 & 7.8 & 8.0 & 7.9 & $\mathbf{7 . 8}$ \\
\hline A & 8.1 & 8.0 & 8.0 & 8.3 & 8.2 & $\mathbf{8 . 1}$ \\
\hline B & 8.5 & 8.4 & 8.6 & 8.4 & 8.5 & $\mathbf{8 . 5}$ \\
\hline C & 8.3 & 8.1 & 8.2 & 8.4 & 8.2 & $\mathbf{8 . 2}$ \\
\hline SE+- & 0.0866 & 0.05893 & 0.077 & 0.10069 & 0.10138 & $\mathbf{0 . 0 9 3 5 4}$ \\
\hline $\begin{array}{c}\text { CD@1 } \\
\text { \% }\end{array}$ & $\mathbf{0 . 3 5 7 7 5}$ & $\mathbf{0 . 2 4 3 4 2}$ & $\mathbf{0 . 3 1 9}$ & $\mathbf{0 . 4 1 5 9 5}$ & $\mathbf{0 . 4 1 8 7 9}$ & $\mathbf{0 . 3 8 6 4 1}$ \\
\hline
\end{tabular}

Table.8 Mean sensory values of sour cream salad

\begin{tabular}{|c|c|c|c|c|c|}
\hline Sample & $\begin{array}{c}\text { Colour \& } \\
\text { Appearance }\end{array}$ & Taste & Flavour & Mouthfeel & $\begin{array}{c}\text { Overall } \\
\text { Acceptability }\end{array}$ \\
\hline EC & 8.3 & 7.8 & 7.9 & 7.6 & $\mathbf{7 . 9}$ \\
\hline A & 8.0 & 8.1 & 8.1 & 8.1 & $\mathbf{8 . 2}$ \\
\hline B & 8.2 & 8.4 & 8.3 & 8.4 & $\mathbf{8 . 5}$ \\
\hline C & 8.4 & 8.7 & 8.6 & 8.7 & $\mathbf{8 . 7}$ \\
\hline SE \pm & 0.11902 & 0.08416 & 0.11844 & 0.0866 & $\mathbf{0 . 0 8 8 1 9}$ \\
\hline CD@1\% & $\mathbf{0 . 4 9 1 6 8}$ & $\mathbf{0 . 3 4 7 6 7}$ & $\mathbf{0 . 4 8 9 2 6}$ & $\mathbf{0 . 3 5 7 7 5}$ & $\mathbf{0 . 3 6 4 3 1}$ \\
\hline
\end{tabular}

Table.9 Mean sensory values of sour cream boondi raita

\begin{tabular}{|c|c|c|c|c|c|c|}
\hline Sample & $\begin{array}{c}\text { Color and } \\
\text { appearance }\end{array}$ & Taste & Flavour & $\begin{array}{c}\text { Textur } \\
\text { e }\end{array}$ & Mouthfeel & $\begin{array}{c}\text { Overall } \\
\text { acceptability }\end{array}$ \\
\hline EC & 8.2 & 8.3 & 8.1 & 8.2 & 8.2 & $\mathbf{8 . 2}$ \\
\hline $\mathbf{A}$ & 8.5 & 8.4 & 8.3 & 8.5 & 8.4 & $\mathbf{8 . 4}$ \\
\hline SE \pm & 0.03727 & 0.08165 & 0.07265 & $\begin{array}{c}0.0471 \\
4\end{array}$ & 0.05137 & $\mathbf{0 . 0 8 3 3}$ \\
\hline $\begin{array}{c}\text { CD@1 } \\
\text { \% }\end{array}$ & $\mathbf{0 . 1 5 3 9 5}$ & $\mathbf{0 . 0 3 7 2 9}$ & $\mathbf{0 . 0 3 0 0 1}$ & $\begin{array}{c}\mathbf{0 . 1 9 4 7} \\
\mathbf{3}\end{array}$ & $\mathbf{0 . 2 1 2 2 1}$ & $\mathbf{0 . 3 4 4 2 4}$ \\
\hline
\end{tabular}

Table.10 Microbial characteristics of sour cream

\begin{tabular}{|c|c|c|c|}
\hline $\begin{array}{c}\text { Storage } \\
\text { (in days) }\end{array}$ & $\begin{array}{c}\text { Total Plate Count } \\
(\mathbf{C F U} / \mathbf{g}) \mathbf{x 1 0}\end{array}$ & $\begin{array}{c}\text { Yeast and Mold count } \\
(\mathbf{C F U} / \mathbf{g}) \mathbf{1 0} \mathbf{3}^{\mathbf{3}}\end{array}$ & $\begin{array}{c}\text { Coliform } \\
\text { Count }\end{array}$ \\
\hline $\mathbf{0}$ & 2.7 & ND & ND \\
\hline $\mathbf{8}$ & 4.3 & ND & ND \\
\hline $\mathbf{1 6}$ & 5.8 & 3 & ND \\
\hline $\mathbf{2 4}$ & 7.5 & 5 & ND \\
\hline $\mathbf{3 2}$ & $\mathbf{8 . 6}$ & $\mathbf{6}$ & ND \\
\hline
\end{tabular}


Table.11 Theoretical energy value of sour cream

\begin{tabular}{|l|c|}
\hline \multicolumn{1}{|c|}{ Parameter } & Energy value $(\mathrm{kcal})$ \\
\hline Protein & 6.88 \\
\hline Crude fat & 144 \\
\hline Carbohydrate & 29.16 \\
\hline Total energy & $\mathbf{1 8 0 . 0 4}$ \\
\hline
\end{tabular}

Fig.1 Sensory evaluation of sour cream spread prepared with addition of flavouring agents

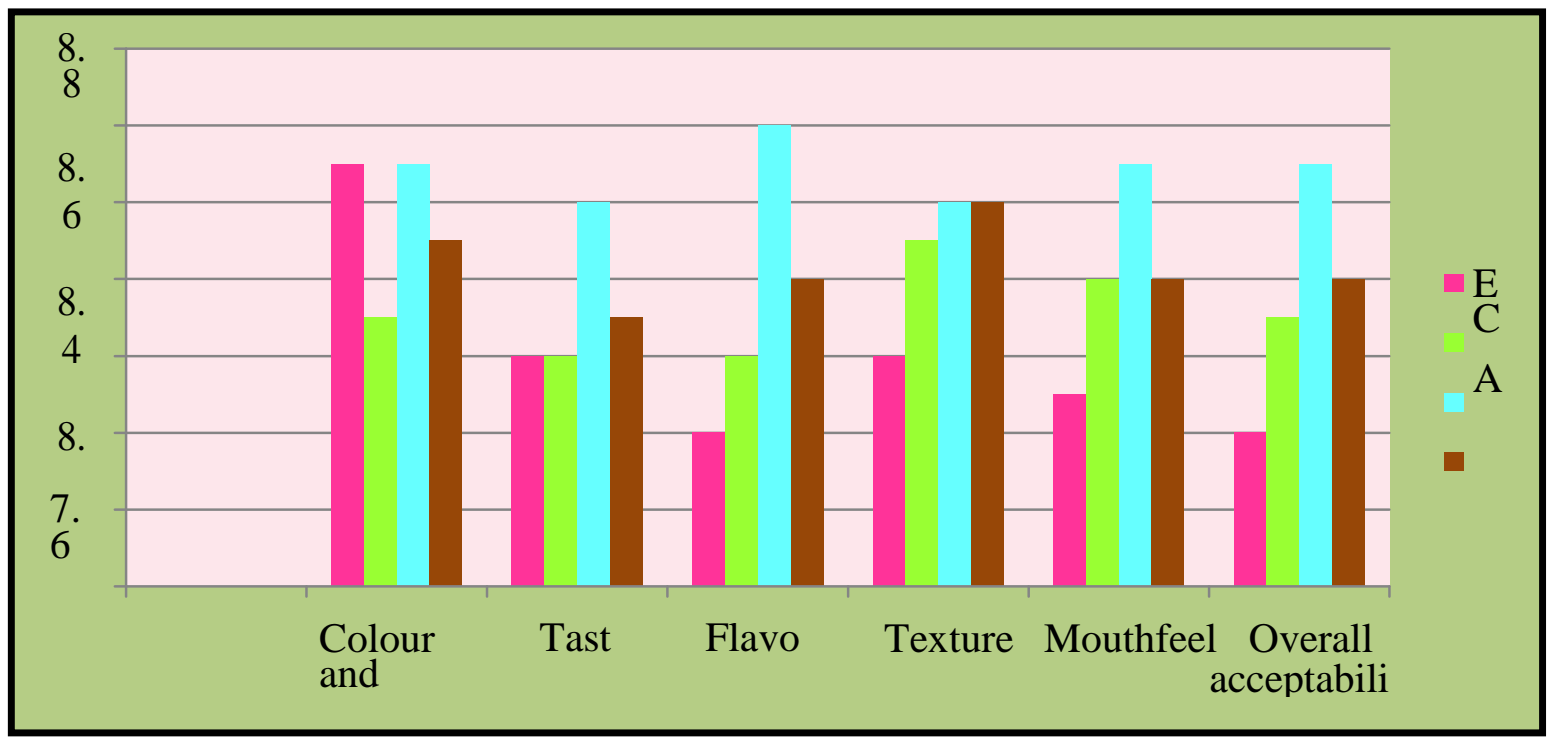

Fig.2 Sensory characteristics of sour cream salad

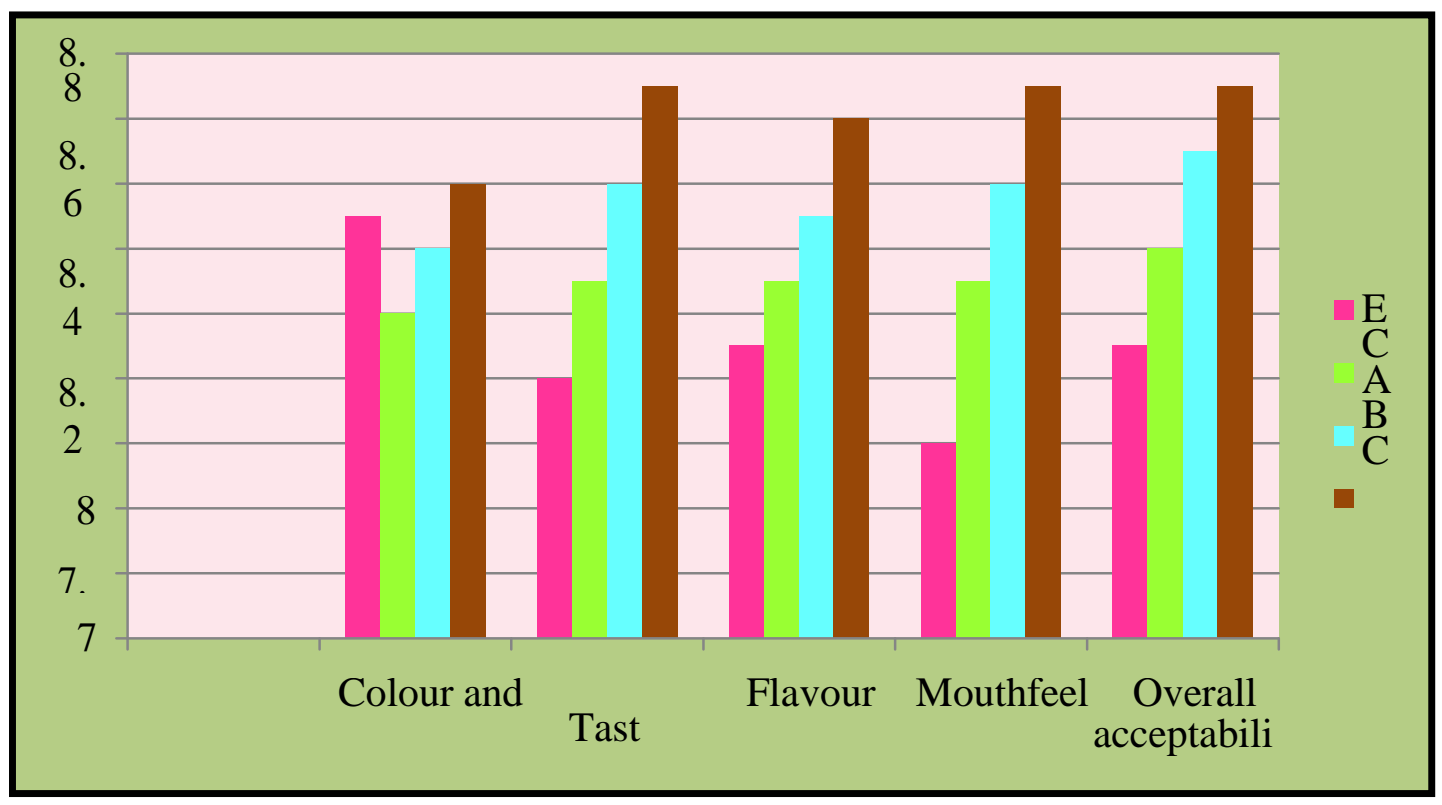


Fig.3 Sensory characteristics of sour cream boondi raita

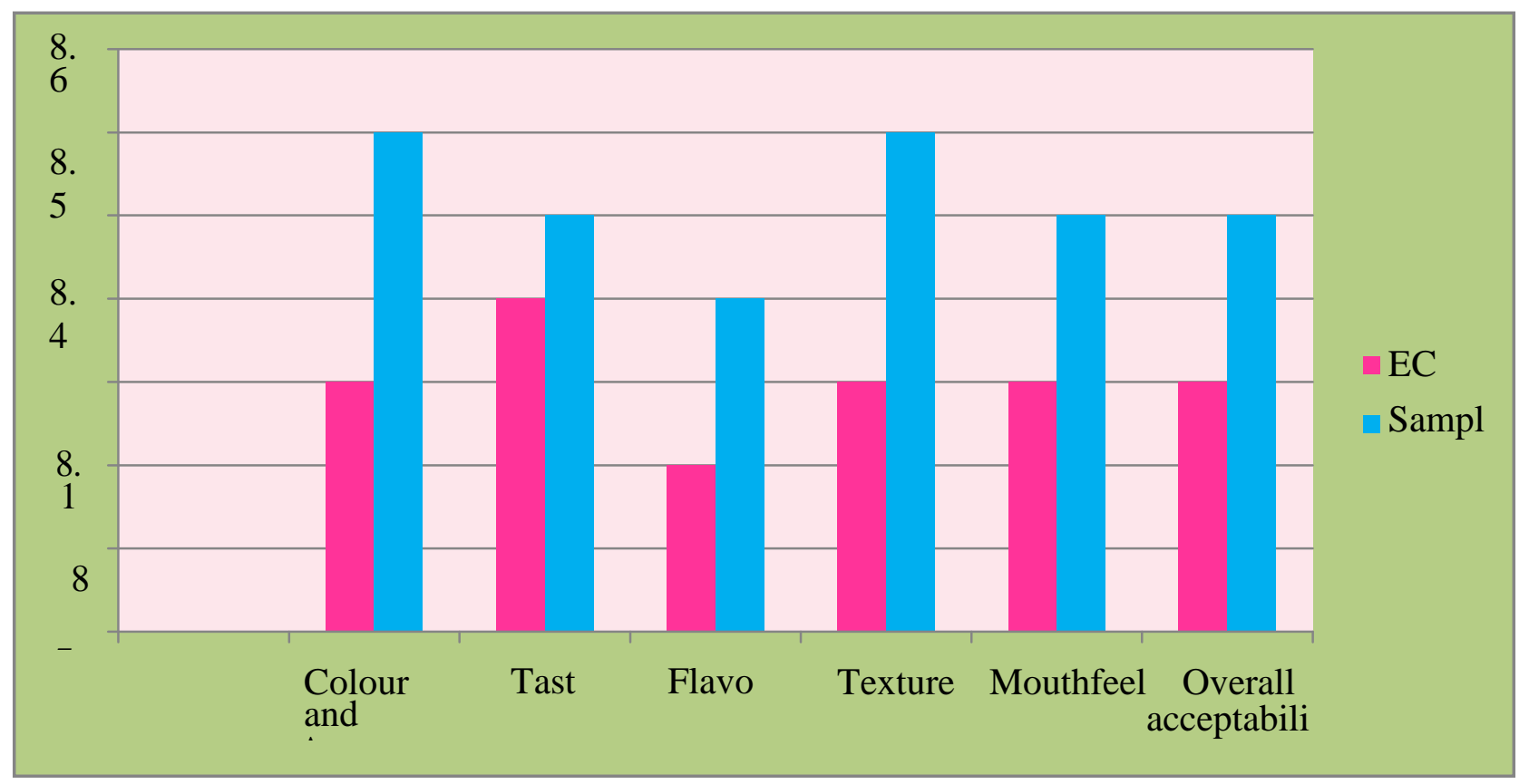

Flow Chart 1: Preparation of Sour Cream Spread with flavouring ingredients

Preparation of cream Standardization with milk to $18-19 \%$ fat, $7-9 \%$ SNF

Pasteurization at $74^{\circ} \mathrm{C}$ for 30 min Continuous stirring

Cool to $22^{\circ} \mathrm{C}$ Addition of starter culture $(6 \%)$

Addition of xanthan gum $(0.2 \%)$

Packaging (Packaging glass jars sterilized in autoclave at $121^{0} \mathrm{C}$ for $15 \mathrm{psi}$ )

$\checkmark$

Incubation at $22^{\circ} \mathrm{C}$ till acidity reaches to $0.5 \%$

Cool to $2{ }^{\circ} \mathrm{C}$ and hold $24 \mathrm{hr}$

\section{Sour cream}

Addition of flavour ingredients

(Jaljira masala, red chili sauce, green chili sauce)

$\downarrow$

Sour Cream Spread 
Flow Chart 2 Preparation of Sour Cream Salad

Selection of raw materials

(Cabbage, cucumber, tomato, carrot, pomegranate, grapes, spinach)

Washing and cleaning with cold water

Weigh according to the formulation

Cut into small pieces

Addition of seasonings (salt, chat masala, chili sauce)

$\downarrow$

Addition of sour cream

Mix thoroughly

$\downarrow$

Sour cream salad (packed in glass jar)

Flow Chart 3 Preparation of Sour Cream Boondi Raita

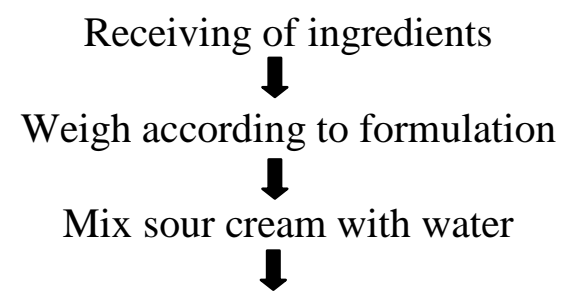

Addition of salt, sugar, coriander, salt and chat masala as per the formulation

\section{$\downarrow$}

Dip boondi into water, remove it and add to the sour cream mixture

\section{$\downarrow$}

Garnish the mixture with red chili powder

Cool the mixture in refrigerator

Boondi Raita

\section{Theoretical energy value of sour cream}

Theoretical energy value of acceptable sample of sour cream was determined by addition of energy value obtained from crude fat, crude protein and total carbohydrates. Table 11 summarizes the energy value i.e. $180.04 \mathrm{kcal}$ of acceptable sample of sour cream.

In conclusion, sour cream was prepared by ripening of cream with the addition 6\% culture of Lactic Acid Bacteria (Lactobacillus 
acidophilus and Streptococcus lactis) culture and $0.2 \%$ xanthan gum. Sour cream thus produced was found to be high in nutritional content. It was found that sour cream spread with red chili sauce with $20 \%$ sour cream had higher overall acceptability. Sour cream spread can be a good substitute for mayonnaise which is high in fat content. Sour cream can be used upto $20 \%$ in the salad preparation. Also, sour cream can be utilized in the preparation of boondi raita which was found to be more acceptable than the boondi raita prepared with curd. Further, the shelf life of sour cream is found to be for four weeks at the refrigerated storage condition.

\section{References}

AOAC (1990). Official Methods of Analysisi $15^{\text {th }}$ Edtn. The association of Official analytical chemists, Arlington, Virginia, USA

Beshkova D., Simova E., Frengova G., Simov $\mathrm{Z}$ (1998). Production of flavour compounds by yoghurt starter cultures. J. Industrial Microbiology \& Biotechnology 20: 180-186.

Deman, J.R.; Rogosa, M. And Sharpe, M.E. (1960). A Medium for Cultivation of Lactobacilli. J. Appl. Bact. 23: 130-135.

Ghadge P. N., Prasad K., and Kadam P.S. (2008). Effect of fortification on the physic-chemical and sensory properties of buffalo milk yoghurt. Electronic Journal of Environmental Agriculture of Food Chemistry., 7(5): 2890-2899.

Grajek, W., Olejnik A. and Sip, A. (2005). Probiotics, prebiotics and antioxidantsvas functional foods. Acta Biochim Pol. 52: 665-671.
Khem M. Shahani (1979). Nutritional and Healthful Aspects of Cultured and Culture-Containing Dairy Foods. Journal of Dairy Science Vol. 62, No. 10.

Kwan, A.J., Kilara A., Friend B.A., and Shahani K.M. (1982). Comparative BVitamin Content and Organoleptic Qualities of Cultured and Acidified Sour Cream. Journal of Dairy Science Vol. 65, No.5.

Lipatov, N.N., A.V. Piranishvili., G.V. Fridenberg., and V.M. Tskitishvili. (1978). Tvorog production from reconstituted milk based on continuous protein coagulation. Page 817 in Proc.

XX Int. Dairy Cong. Vol. BC.

Manual of methods of analysis of foods (2012). Food Safety And Standards Authority of India. Ministry Of Health And Family Welfare. Government Of India, New Delhi.

Manual of Methods of Analysis of Foods: Milk and Milk Products (2005). Directorate General of Health Services, Ministry of Health and Family Welfare, Government of India, New Delhi.

Meilgaard, B., Morten C., Thomas Carr., Gail Vance Civille (2006). Sensory Evaluation Techniques. Ed.4, CRC Press.

Panse, V. G. and Sukhatme, P. V. (1985). Statistical Methods for Agricultural Workers, Edn. 2, ICAR, New Delhi.

Pavey Robert L., Western Springs; Patrick E. Mone, Oak Lawn, both of III. (1976). Shelf -Stable Low-Fat Biologically Fermented Dairy Product. United States Patent 3,969,534.

Sukumar De (1991). Outlines of Dairy Technology. Pub: Oxford University of Delhi.

\section{How to cite this article:}

Katke, S.D., Mohammed Abdur Rahman and Patil, P.S. 2019. Standardization and Quality Evaluation of Sour Cream Enriched Therapeutic Food Products. Int.J.Curr.Microbiol.App.Sci. 8(03): 1449-1461. doi: https://doi.org/10.20546/ijcmas.2019.803.169 